DOI: $10.24326 /$ fmpmsa.2017.24

\title{
ENERGETIC USAGE OF SLAUGHTER WASTE AS THE SUBSTRATE FOR BIOGAS PRODUCTION
}

\author{
Damian JANCZAK, Kamil KOZLOWSKI, Michal BRZOSKI, \\ Aleksandra JEŻOWSKA, Jakub MAZURKIEWICZ \\ Poznan University of Life Sciences, POLAND \\ E-mail of corresponding author: damian.janczak@up.poznan.pl
}

Keywords: biogas, slaughter waste, energetic usage

\begin{abstract}
Sector of animal production is growing strongly in Poland within last years. This concerns especially poultry sector (first position in Europe with more than 900 million animals per year) bit also swine and cattle. This sector generates dynamic growth of meat export. However, this sector is responsible also for large scale production of slaughter waste which very often creates problem with its proper management and recycling. This paper describes the possibility of the energetic usage of slaughter waste as the substrate for biogas production. The biogas efficiency analysis of different waste like: waste category II, blood, feathers, soft waste category III and solid waste category III have shown its good usefulness for methane production. The calculations showed the energetic potential for analyzed slaughter house as $700 \mathrm{kWe}$.
\end{abstract}

\section{INTRODUCTION}

The most important factor determining the profitability of the agricultural biogas plant is type of the substrate used (except for technology used) (Ward et al., 2008). Maize silage, supplemented with animal excrements, predominates among the substrates in the whole Europe (Naik et al., 2010; Herrmann et al., 2015). These substrates can be used in the most common German technology NaWaRo spread on the continent (Dach et al., 2014). As a result of very low subsidies for energy produced from biogas in 2012-2016 (Wędzik at al., 2017), new and innovative technologies have emerged in Poland as a global vanguard in the field of highly efficient biogas waste treatment. Production results of installation in Międzyrzec Podlaski, Jaromierz or Upałty reach 8500 MWh from 1 MW of installed electrical power, which gives the efficiency at the level of $97 \%$. As these biogas plants primarily use organic waste, it is evident that biogas plants primarily should use for fermentation processes the waste biomass and dispose animal waste.

In the meantime, in Poland, the use of slaughterhouse waste and carcase in biogas plants is almost completely ignored. Although research conducted at the Laboratory of Ecotechnologies in the Institute of Biosystems Engineering (Poznan University of Life Sciences, PULS) proves that these are very promising substrates, however, investors are afraid of this kind of waste (Cieślik et al., 2016b), Czekała et al., 2015). This is due to the fact that not every technology is able to efficiently digest all parts of the animal's body or carcass. It should be highlighted, that among the substrates used for the production of agricultural biogas, among the slaughterhouse waste there is a distinction i.e. fat issue, stomach contents, flea fats, feathers, blood or skin - and sometimes sediment from the sewage treatment plant and often slurry. The usefulness of the discussed substrates for fermentation is mainly related to the high content of fats and proteins, which is usually very high. 
The slaughterhouse waste materials are strongly differentiated both physically, chemically and microbiologically and therefore should be used in installations dedicated to the processing of a wide range of waste, such as ProBioGas technology from Bio Power company from Międzyrzec Podlaski or Dynamic Biogas from Poznań. However, it is important to remember that in any technology it is necessary to subject the waste to thermal treatment before being dumped into the fermentation chamber.

An additional advantage in the waste disposal in the biogas plant is, on the one hand, an answer to the waste and environmental problems for the plant, and a significant reduction of odors generated by the stored and disposed waste (Czekała et al., 2016a). Composting is another type of organic waste management (Wolna-Maruwka and Czekała, 2007). The process allows recycling of waste and the final product of the process is valuable fertilizer compost (Białobrzewski et al., 2015; Waszkielis et al., 2013). Moreover, it is important to implement problematic waste for electricity and heat production and to ensure the energy self-sufficiency for the slaughterhouse. It should be remembered, that the acceptance of post-mortem residues in the biogas plant, still continues to preserve the status of an agricultural installation (of course, once the relevant requirements have been met). European Union legislation divides slaughter waste into three categories. In the biogas plants, after prior pre-treatment, only waste materials that are classified as category II (e.g. digestive tract) and category III (e.g. inedible parts of animals) can be used.

Meat production is characterized by considerable variation in the processes and the technologies used. Very often, different types of slaughterhouse waste can occur in different plants from the same animals. The best example are fatty and flotation deposits, where the content of dry matter and hence the productivity of methane can vary significantly between slaughterhouses.

The use of slaughterhouse waste, as a biogas substrate, makes it easy to improve the economic efficiency of the installation. The purchase cost is small (0-50 PLN/Mg), compared to the popularly used in the methane fermentation maize silage (100-130 $\mathrm{PLN} / \mathrm{Mg}$ ). Moreover, in some cases, it is possible to get extra revenue for the management of this kind of waste. Another benefit may be the sale of post-fermentation, which is a valuable fertilizer (Czekała et al., 2017; Czekała et al., 2016b).

The aim of this paper is to analyze an energetic usage of slaughter waste as the substrate for biogas production based on study-case of middle size meat factory in South-West Poland. The investor is going to build biogas plant connected with the poultry slaughter house in order to reduce the problems related to waste management, as well as increase the economic balance of the company.

\section{MATERIALS AND METHODS}

For the analysis, the waste substrates from the poultry slaughterhouse were taken directly from the slaughter plant and after cooling, were transported immediately to the Laboratory of Ecotechnology for basic analysis and determination of the biogas efficiency. The following types of waste were collected:

- waste category II;

- blood; 
- feathers;

- soft waste category III;

- solid waste category III.

The fermentation inoculum used to verify the biogas efficiency of the substrates was obtained by separating the fraction of liquid fermentation pulp from a functioning agricultural biogas plant.

The dry mass (PN-75 C-04616/01) and dry organic mass (PN-Z-15011-3) were tested to determine the appropriate ratio between the tested substrate and the inoculum (WolnaMaruwka, 2012). These parameters were also necessary to calculate the biogas efficiency of the substrates per $\mathrm{m}^{3} / \mathrm{Mg}$ F.M. (fresh mass), $\mathrm{m}^{3} / \mathrm{Mg}$ D.M. (dry mass) and $\mathrm{m}^{3} / \mathrm{Mg}$ O.D.M. (organic dry mass). The analysis of the biogas efficiency of the substrates was carried out at the Laboratory of Ecotechnology in the Poznan University of Life Sciences, on the basis of internal procedures based on the internationally recognized German standard DIN 38 414/S8 and the standardized biogas guide of the German Engineers Association in Dresden - VDI 4630.

The research experiments were carried out in the reactors with capacity of $2 \mathrm{dm}^{3}$ in $39^{\circ} \mathrm{C} \pm$ 1 water bath (mesophilic fermentation), which are part of the 21-reactor research stations constructed in the Laboratory of Ecotechnology (Fig.1). The qualitative and quantitative analysis of the produced gases $\left(\mathrm{CH}_{4}, \mathrm{CO}_{2}, \mathrm{NH}_{3}, \mathrm{O}_{2}, \mathrm{H}_{2} \mathrm{~S}\right)$ was performed every day using the Geotech GA5000 gas analyzer (Cieślik et al., 2016).

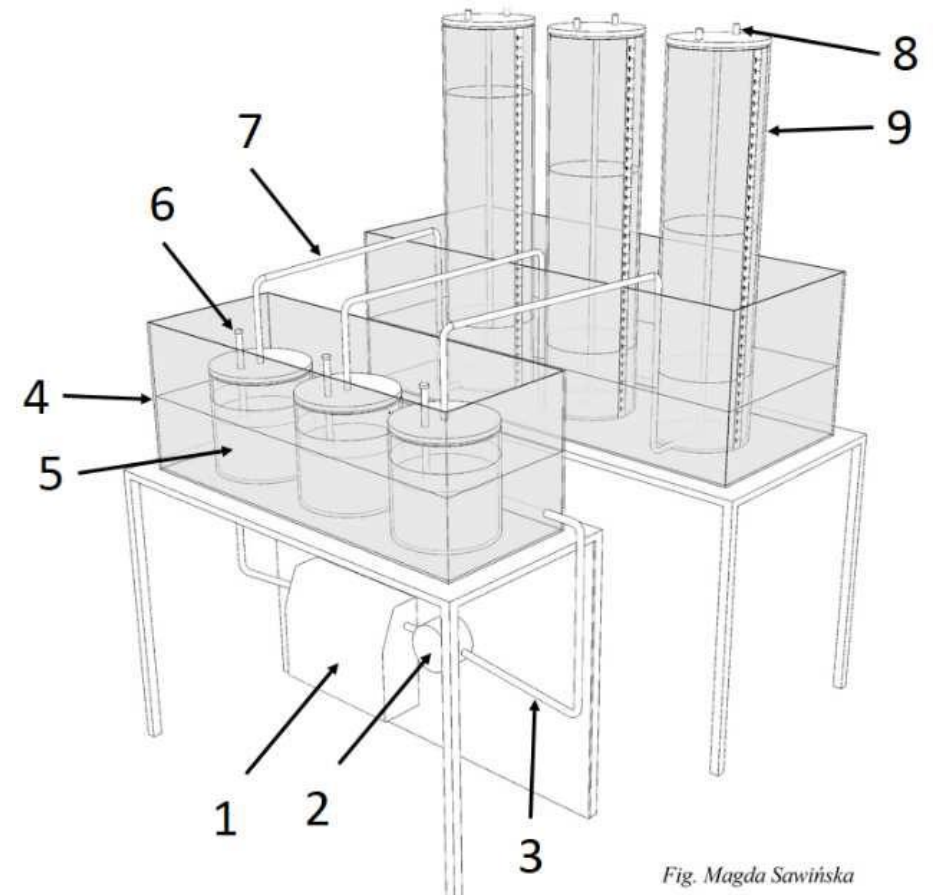

Fig.1. Scheme of biofermenter for biogas production research (3-chamber section): 1 - water heater with a temperature in the range of $20-70^{\circ} \mathrm{C}, 2$ - water pump, 3 - isolated hot liquid tube, 4 - layer of water at temperature of $38^{\circ} \mathrm{C}, 5$ - biofermentor with the input of $1.4 \mathrm{dm} 3$ of capacity, 6 - sampling tube, 7 - tube for biogas flow, 8 - security valves (also used for taking biogas samples), 9 - biogas container made of poly (methyl methacrylate). 
The energetic calculations were made according to the methodology created by the Institute of Biosystems Engineering, in close co-operation with the enterprises from Polish biogas sector (Cieślik et al., 2016).

\section{RESULTS}

\section{Physical and biogas analysis}

The results of the analysis of basic physical parameters of waste used as substrates are presented in Table 1.

Tab. 1. The basic parameters of analyzed substrates

\begin{tabular}{|l|c|c|}
\hline Substrate & Dry Mass [\%] & $\begin{array}{c}\text { Organic Dry Mass [\% } \\
\text { D.M.] }\end{array}$ \\
\hline waste category II & 20.88 & 71.14 \\
\hline blood & 17.58 & 94.62 \\
\hline feathers & 12.90 & 98.75 \\
\hline soft waste category III & 46.78 & 97.52 \\
\hline solid waste category III & 47.11 & 70.36 \\
\hline
\end{tabular}

As it can be noticed in Table 2, excluding Category II waste and Category III hard waste, other waste materials are characterized by very high organic matter content. Category III wastes, on the other hand, have high dry matter content, which is advantageous for their use in methane fermentation.

However, the results of methane efficiency tests (Table 2) showed, that the highest efficiency of $\mathrm{CH}_{4}$ production was noticed in case of Category II waste $\left(406.57 \mathrm{~m}^{3} / \mathrm{Mg}\right)$, where dry matter content was more than half that of Category III waste.

Tab. 2. The results of methane efficiency tests

\begin{tabular}{|l|c|c|c|}
\hline Substrate & Methane content [\%] & $\begin{array}{c}\text { Cumulated methane } \\
{\left[\mathrm{m}^{3} / \mathrm{Mg} \text { D.M. }\right]}\end{array}$ & $\begin{array}{c}\text { Cumulated biogas } \\
{\left[\mathrm{m}^{3} / \mathrm{Mg} \mathrm{F.M.]}\right.}\end{array}$ \\
\hline waste category II & 69 & 406.57 & 589.23 \\
\hline blood & 67 & 56.44 & 84.24 \\
\hline feathers & 68 & 14.57 & 21.42 \\
\hline soft waste category III & 70 & 282.63 & 403.75 \\
\hline solid waste category III & 69 & 155.17 & 224.89 \\
\hline
\end{tabular}

As a result of mesophilic fermentation of slaughterhouse waste, calculated as $1 \mathrm{Mg}$ of fresh matter, most of biogas was obtained from waste category I, nearly $590 \mathrm{~m}^{3}$, whereas least methane was obtained from fermentation of feathers as only about $21.5 \mathrm{~m}^{3}$. All waste materials were characterized by an average methane content of about $70 \%$. This is a very high result, by almost 20 percentage points higher than the methane content of the typical biogas produced from silage (methane content of 48-53\%). On this basis, it should be emphasized that slaughter waste is much more energetic substrate than typical plant products used to supply biogas plants. It is also important to emphasize that the use of slaughterhouse waste to supply agricultural biogas plant enables it to continue to retain agricultural status, which means higher level of subsidy for energy produced compared to municipal waste treatment facilities and also facilitates (from a legal point of view) the use of post-fermentation as fertilizer agricultural. 


\section{Energetic analysis}

Table 1 represents the results of energy calculations for the yields obtained for substrates as well as the total mass produced by the slaughterhouse.

Tab. 1. Results of energy calculations for the analyzed poultry slaughterhouse

\begin{tabular}{|l|c|c|}
\hline Substrate mass & 9120 & $\mathrm{Mg}$ \\
\hline Total volume of methane produced & $1,570,539$ & $\mathrm{~m}^{3}$ \\
\hline Total volume of biogas produced & $2,255,600$ & $\mathrm{~m}^{3}$ \\
\hline The amount of electricity produced & 6048.77 & $\mathrm{MWh}$ \\
\hline The amount of thermal energy produced & 6480.83 & $\mathrm{MWh}$ \\
\hline The amount of thermal energy produced & 23652.66 & $\mathrm{GJ}$ \\
\hline Electrical efficiency of the aggregate & 0.43 & {$[-]$} \\
\hline Thermal performance of the aggregate & 0.45 & {$[-]$} \\
\hline Electric power of the biogas plant & 0.70 & $\mathrm{MW}$ \\
\hline Thermal power of the biogas plant & 0.75 & $\mathrm{MW}$ \\
\hline
\end{tabular}

In total, during the year, the average poultry slaughter plant produces over $9100 \mathrm{Mg}$ of waste. From this mass, it can be produced more than 1.5 million $\mathrm{m}^{3}$ of methane. By burning this volume of methane with the efficiency of the cogeneration unit $43 \%$ we can produce over 6000 MWh electricity.

Assuming the operating time of the cogeneration unit at the level of $8600 \mathrm{~h}$ per year, the planned biogas plant will have an electrical power of $0.7 \mathrm{MW}$.

\section{CONCLUSIONS}

1. The slaughterhouse waste (especially category II) is an energy waste that is suitable for use in agricultural biogas.

2. Very high methane content in biogas produced from slaughterhouse waste and high (up to 4 times) methane yields than in case of maize silage, makes these waste materials much more profitable for use in biogas plant than typical agricultural substrates.

3. In the analyzed case study, the electricity generated from the waste can cover completely the own needs of the plant.

4. The use of slaughterhouse waste for methane fermentation has a positive effect on the reduction of odors generated by stored and disposed waste.

\section{REFERENCES}

Białobrzewski, I., Mikš-Krajnik, M., Dach, J., Markowski, M., Czekała, W., Głuchowska, K. (2015). Model of the sewage sludge-straw composting process integrating different heat generation capacities of mesophilic and thermophilic microorganisms. Waste Management 43. 72-83.

Cieślik, M., Dach, J., Lewicki, A., Smurzyńska, A., Janczak, D., Pawlicka-Kaczorowska, J., Boniecki, P., Cyplik, P., Czekała, W., Jóźwiakowski, K. (2016). Methane fermentation of the maize straw silage under meso- and thermophilic conditions. Energy 115(2), 1495-1502. 
Czekała, W., Dach, J., Ludwiczak, A., Przybylak, A., Boniecki, P., Koszela, K., Zaborowicz, M., Przybył, K., Wojcieszak, D., Witaszek, K. (2015). The use of image analysis to investigate C:N ratio in the mixture of chicken manure and straw. Proc. SPIE. 9631, Seventh International Conference on Digital Image Processing (ICDIP 2015), 963117. doi: 10.1117/12.2197041.

Czekała, W., Smurzyńska, A., Cieślik, M., Boniecki, P., Kozłowski, K. (2016a). Biogas efficiency of selected fresh fruit covered by the Russian embargo. Energy And Clean Technologies Conference Proceedings, SGEM 2016, VOL III: 227-233.

Czekała, W., Bartnikowska, S., Lewicka, A., Bugała, A., Zbytek, Z., Lewicki, A. (2016b). Economic and energy efficiency of the solid biofuels produced from digested pulp. MATEC Web of Conferences 60, 04005 ICCBS 2016. DOI: $10.1051 /$ matecconf/20166004005

Czekała, W., Dach, J., Dong, R., Janczak, D., Malińska, K., Jóźwiakowski, K., Smurzyńska, A., Cieślik, M. (2017). Composting potential of the solid fraction of digested pulp produced by a biogas plant. Biosystems Engineering 160, 25-29.

Dach J., Boniecki P., Przybył J., D. Janczak, A. Lewicki, W. Czekała, K. Witaszek, P.C. Rodriguez Carmona, Cieślik. M. (2014). Energetic efficiency analysis of the agricultural biogas plant in $250 \mathrm{~kW}(\mathrm{e})$ experimental installation. Energy, 69, 34-38

Herrmann C., Idler C., Heiermann M. (2015). Improving aerobic stability and biogas production of maize silage using silage additives. Bioresource Technology, 197, Pages 393-403

Naik S.N., Goud V.V., Rout P.K., Dalai A.K. (2010). Production of first and second generation biofuels: a comprehensive review. Renew. Sustain. Energy Rev., 14, 578-597.

Ward A.J., Hobbs P.J., Holliman P.J., Jones D.L. (2008). Optimisation of the anaerobic digestion of agricultural resources. Bioresour. Technol., 99, 7928-7940

Waszkielis K.M., Wronowski R., Chlebus W., Białobrzewski I., Dach J., Pilarski K., Janczak D. (2013). The effect of temperature, composition and phase of the composting process on the thermal conductivity of the substrate. Ecological Engineering 61(A), 354-357.

Wędzik A., Siewierski T., Szypowski M. (2017). Green certificates market in Poland - The sources of crisis. Renewable and Sustainable Energy Reviews, 75, 490-503

Wolna-Maruwka A. (2012). Impact of the inoculation with BAF preparation on microbiological and biochemical parametres of sewage sludge composting. Fresenius Environmental Bulletin. 21(2a), 413-425.

Wolna-Maruwka A., Czekała J. (2007): Dynamics of changes in the number of selected microorganism groups in sewage sludge and in manure subject to composting process and in the soil enriched with composts. Archives of Environmental Protection 33(4), 53-66. 